\title{
Economic-Ecological Values of Non-Tidal Swamp Ecosystem: Case Study in Tapin District, Kalimantan, Indonesia
}

\author{
Hamdani $^{1,6}$, Imam Hanafi ${ }^{2}$, Anwar Fitrianto ${ }^{3,4,5}$, Lutfhi Fatah Arsyad $^{6} \&$ Budi Setiawan $^{7}$ \\ ${ }^{1}$ Graduate Program, Environmental Science and Technology, University of Brawijaya, Indonesia \\ ${ }^{2}$ Departement of Public Administration, University of Brawijaya, Indonesia \\ ${ }^{3}$ Department of Mathematics, Faculty of Science, Universiti Putra Malaysia, Malaysia \\ ${ }^{4}$ Institute for Mathematical Research, Universiti Putra Malaysia, Malaysia \\ ${ }^{5}$ Department of Statistics, Faculty of Mathematics and Natural Resources, Bogor Agricultural University, \\ Indonesia \\ ${ }^{6}$ Department of Agribusiness, University of Lambung Mangkurat, Indonesia \\ ${ }^{7}$ Departemen $t$ of Agricultural Economic, University of Brawijaya, Indonesia \\ Correspondence: Anwar Fitrianto, Department of Mathematics, Faculty of Science, Universiti Putra Malaysia, \\ Mathematics Building, Universiti Putra Malaysia 43400, Serdang Selangor, Malaysia. E-mail: \\ anwarstat@gmail.com
}

Received: August 29, 2013

doi:10.5539/mas.v8n1p97
Accepted: October 9, $2013 \quad$ Online Published: January 2, 2014

URL: http://dx.doi.org/10.5539/mas.v8n1p97

\begin{abstract}
This article would like to describe the economic and ecological benefits, as well as analyzing the total economic value of non-tidal swamps. Non-tidal swamps in the District Tapin are interested to be studied because of the use of non-tidal swamp in this area for people, especially ethnic Banjar since over a hundred years ago. But since 2011 the South Kalimantan local government has set a palm oil plantation development plans (Elaeis guineensis) on the area. Assessment has been conducted with a total valuation approach (total valuation). We found that the ecosystem has economic benefits in the form of functions of water supply for rice paddy (Oryza sativa), timber plants (Melaleca cajuputi), fisheries, Purun plants (Eleocharis dulcis), and functions as a source of domestic water. It has also ecological benefits in the form of biological functions such as: the provision of feed (feeding ground), where fish rearing, timber Galam (nursery ground), and hatchery fish (spawning ground), as storage and recycle of water, and function options (option value) in the form of biodiversity. Based on the results of the assessment are known, the total economic value amounted to 22.7 million per hectare, with the ratio of the economic value of only $7.14 \%$ compared to the ecological value of $92.86 \%$. Therefore non-tidal swamps conversion plan into another function not only the loss of economic value (direct benefits) that had been in the swamp enjoy the surrounding community, but also a greater loss in the form of loss of ecological value (indirect benefits).
\end{abstract}

Keywords: swamp, total valuation, economic-ecological value

\section{Introduction}

Challenges and issues that must be faced now are how development activities can provide benefits to all parties, as well as take into account the needs of present and future generations. This fits the legal basis discretion of natural resource management and the environment that prior to the implementation, a development activity should be a careful assessment of the impact on the environment, economy and ecology. In Indonesia, there are extensive wetlands with around 33.4 million hectares which are spread on over 11 provinces. Out of that, there are 12.3 million hectares of swamps found in Borneo in forms of non-tidal swamp area of 6.437 million hectares, and 5.938 million hectares of tidal marsh.

Based on those facts, it is interesting to do a total economic valuation of swamp ecosystem, especially on non-tidal. At the same time, we will get information if the swamp will be converted into another function. The economic value is then defined as benefit analysis of induced or can be retrieved from the swamp forest. In this case, benefits of swamp ecosystem has directs usage and in general has a market value, as well as an analysis of 
the ecological value of the benefit or function caused by non-tidal swamp ecosystem, which includes the function of biology, chemical, physics, and in general is of value to indirectly.

\section{Literature Reviews}

Land use of non-tidal swamp especially for agricultural production in South Kalimantan, including the District Tapin especially Banjar ethnic groups is estimated to have lasted from 200's of years ago (Sabran et al., 1998). Most of them have been doing in agricultural sector such as extensive fishing, peasant food (horticulture, rice), livestock (ducks and buffalos), while others engaged in trade, crafts and services which are all closely related to the utilization of wetlands. It means that there is strong relationship between nature (the swamp) and people around it (Nautiyal \& Rama, 2012). Besides having the function of production and the proliferation of other living things, non-tidal swamp have an important role in the functioning of ecological and environmental services, (Swinton et al., 2006; Turpie et al., 2010; Noor, 2007). Agricultural wetlands such as swamps (Malabika et al., 2012) referred to as multifunctional, such as agriculture, food security functions, socio-cultural, environmental functions (flood mitigation, erosion control, water resource recycling, organic waste absorbent, mitigation of air temperature, and the beauty of rural guards). For example, a wetland in Citarum consists of 156,000 hectares. By using replacement cost method (RCM), it can reach as much as \$181.34 million total per year, and approximately $51 \%$ ( $\$ 92.67$ million per year) of them are obtained from selling the rice. This value is interpreted as the services produced by the farmers and are shared for the public for free (Agus \& Irawan, 2006).

The magnitude of the critical role wetlands means wetlands have a high value in terms of economic, environmental, cultural and others so that we must save it. This is in accordance with Indonesian government regulations about the importance of wetlands. It is also mentioned in the regulation that the natural resources and the environment should be managed with thoughtful and integrated and so thorough development and sustainability of human life can be maintained and sustainable now and in the future. Based on the observations, in particular Indonesian plantation sub-sector, palm plantation development is now experiencing very rapid growth. The rapid development of this sub-sector is because of government policies that provide a variety of incentives, especially in terms of ease of licensing and opening new areas of investment aid for the construction of the garden especially to private estates (Manurung, 2011). The bright future of the expansions of oil palm plantations as well as the convenience provided make many investors interested in investing in these commodities, and growing widely in various areas. In South Kalimantan, development of oil palm plantations is now not only on dry land or minerals but also have widespread and utilized swamps by doing extension on it. If the business plan is actually carried out, the company should play a role in protecting the environment. This kind of action can benefit to both the company and the community (Aimkij et al., 2013). Meanwhile, local government must take a role for caring and reaffirms the important role of proactively monitoring system to help in reducing the threat or risk in future (Pavri et al., 2012).

Indonesian Swamp Pant Research Institute (Balitra, 2011), said that the huge swamp area have some potentials and only 217,269 hectares can be developed for agriculture in South Kalimantan. This means that all potential of non-tidal swamp are dominated entirely by private plantation companies. It also means that the swamps which have been the source of livelihood of the people around it will switch its function. This will certainly pose potential environmental problems and the potential for social conflict, economy, and culture of its own for local residents who are not exposed generally in social and cultural aspects by the relevant government agencies.

\section{Methodology}

\subsection{Method}

The research has been conducted on non-tidal swamp in South Kalimantan Province of Indonesia. The samples were taken in Central Tapin district, which is in the Middle District and Southern District of Candi Laras Tapin and Candi Laras district (Please refer to Figure 1). In this region there are 7 large companies which have a plan to develop oil palm plantations in wetlands, and they have received permission to plan on the location which has about 60,874 hectares. There are also economic activities that utilize the swamp in the location. The study was completed in periods of July to September 2012. In this research we collect both primary and secondary data. Primary data is the data that is retrieved by the economic value of the resources that households utilize swamp, community leaders, stakeholders, expert opinion and others, with interview techniques (using questionnaires). Secondary data is obtained from various sources, such as the results of previous research, publications issued by the competent authority. 


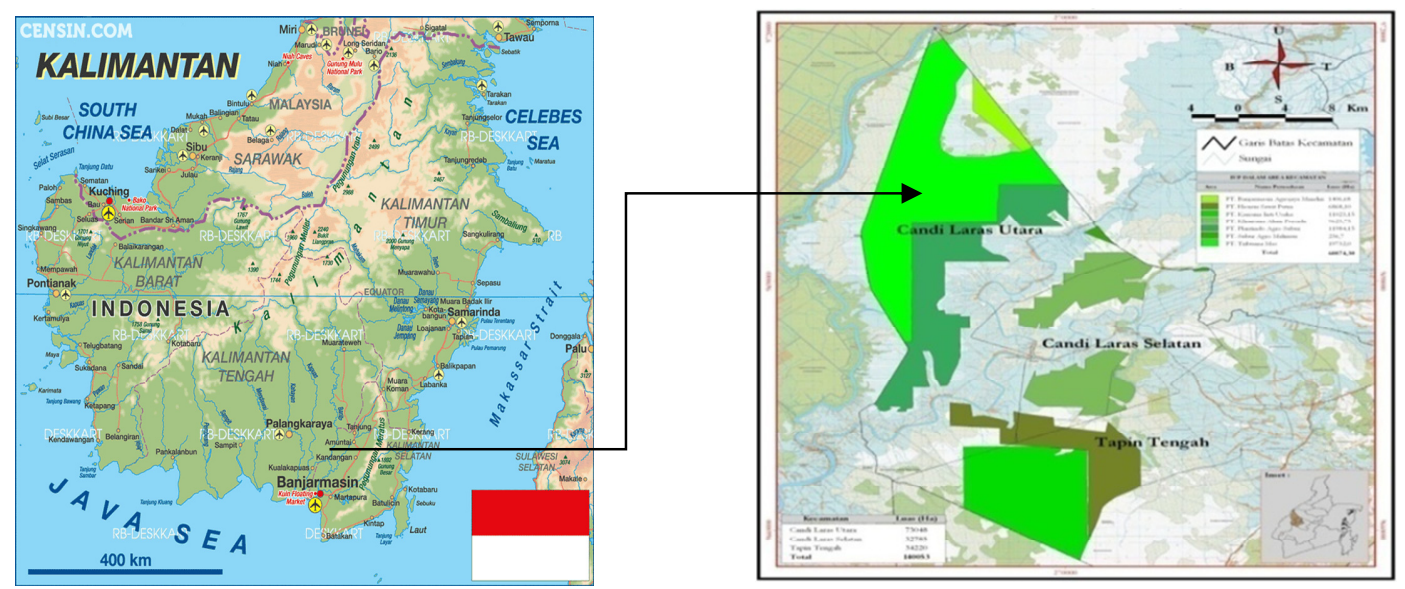

Figure 1. Research site in Tapin Distric of South Kalimantan province

\subsection{Data Analysis}

Appropriate identification of research participants is critical to the science and practice of psychology, particularly for generalizing the findings, making comparisons across replications, and using the evidence in research syntheses and secondary data analyses. If humans participated in the study, report the eligibility and exclusion criteria, including any restrictions based on demographic characteristics. In this research, for data analysis we use economic value method with total valuation approach. By using this method, we predict total economic contribution of a non-tidal swamp ecosystem to the people. The calculation can be written as:

$$
T E V=(D U V+I U V+O V)+(B V)
$$

where:

$T E V=$ total economic value,

$D U V=$ direct use value,

$I U V=$ indirect use value,

$O V=$ option value, and

$B V$ = bequest value.

In this section we also provide some notes about those values as follows:

\subsubsection{Direct Use Value}

Most of the calculations of direct use value regarding non-tidal swamp ecosystem were done using market value approach (Dixon et al., 1994). It is done based on of the average value of production of each commodity produced by farmers, reduced by production costs, then multiplied by the number or the peasant population of each commodity, such as rice (Oryza sativa), Galam wood (Melaleca cajuputi), fish in beje, fisheries, Purun plants (Eleocharis dulcis), and household water.

\subsubsection{Value of Indirect Use}

\section{a) Biological Values}

Calculation of production values of biological function is approximated by calculating the carrying capacity of the non-tidal swamp ecosystem biota such as feed supply places, places or wood fish rearing and spawning of fish per year. By doing this approach, the production value of this function is equivalent to the sum of the total economic value of fishing methods and catching beje fish caught the yield of Galam wood, and Purun crop values.

b) Values of Water Storage and Water Recycling

Calculations to determine the value of the swamp as storage and water recycling is done by replacement cost method. It is done by calculation of potential expenditure, due to the loss of damaged productive assets, with payment of certain amount to get returns back from goods or services that have been lost. 


\section{c) Values of Stored Carbon (VSC) and Emission Prevention (VEP)}

Calculation of the carbon value in this study is assessed by benefit transfer approach that is capability value obtained from the results of previous research (Page et al., 2002). Stored carbon value is calculated as follows:

$$
V S C=S W \times S C \times C P
$$

where,

SW = Size of Swamp Area (hectare),

$\mathrm{SC}=$ Stored Carbon on Particular Swamp (tonne per hectare),

$\mathrm{CP}=$ Carbon Price (Rupiahs per tonne).

\subsubsection{Value of Options (Bio Diversity) and Value of Bequest}

Calculation of the economic value of biodiversity of non-tidal swamp is goods or services which are not traded-environment. The value can be determined by contingent valuation method approach (Mourato et al., 2000). It is a method to determine the willingness of a person, or the public to pay/be paid in order to protect the value of the potential benefits from the utilization of natural resources for the benefit in the future.

\section{Results and Discussion}

\subsection{Direct Use Value}

Based on results of the research and interviews with village and community leaders, we found that $65 \%$ of households in the study area commercialize rice farming as a principal livelihood by planting patterns once a year. The results showed that acreage of cultivated rice farmers is still relatively low at between 0.14 to 1.42 hectares, or 0.77 hectares on average. By using high quality variety of rice paddy, low land swamp can yield 1.87 tonnes of rice paddy per farmer, or 2.433 tonnes per hectare per year. The research was conducted when the

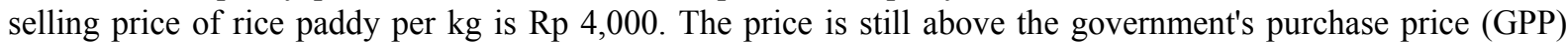

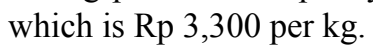

Based on the price of rice paddy at Rp 3,300, plus some amount of subsidy given by the government of Rp 1,300 per $\mathrm{kg}$, the actual price is $\mathrm{Rp} \mathrm{4,600.} \mathrm{This} \mathrm{amount} \mathrm{needs} \mathrm{to} \mathrm{be} \mathrm{deducted} \mathrm{by} \mathrm{Rp} 695,003$ per farmer or Rp $1,103,227$ per hectare for production costs. As a result, the value of rice production is equal to Rp 7,922,315 per farmer. Assume that there are 1067 rice paddy farmer on each 10,000 hectares area, then the total economic value of rice paddy on that area is $\operatorname{Rp} 8,453,110,105$ ( $R p 8,45$ billion) per year or equivalent to USD 88.98 per hectare per year. Details of economic values for rice paddy and other commodities in direct use values are available in Table 1.

Tabel 1. Direct use value of non-tidal swamp ecosystem of sub district Central Tapin and South Candi Laras

\begin{tabular}{llrrr}
\hline & & \multicolumn{3}{c}{ Size of Area } \\
\cline { 3 - 5 } No & Commodities & \multicolumn{1}{c}{$\begin{array}{c}10,000 \text { ha } \\
\text { (Rp per year) }\end{array}$} & $\begin{array}{c}1 \text { ha } \\
\text { (Rp per year) }\end{array}$ & $\begin{array}{r}1 \text { ha } \\
\text { (USD per year) }\end{array}$ \\
\hline 1. & Rice paddy, (amount of & $8,453,110,105$ & 845,311 & 88.98 \\
& $\begin{array}{l}\text { production is 2,433 tonnes } \\
\text { per hectare per year }\end{array}$ & & & 8.87 \\
2. & Galam wood & $842,959,836$ & 84,296 & 15.74 \\
3. & Beje fishing & $1,495,320,604$ & 149,532 & 41.94 \\
4. & Common fishing & $3,984,048,000$ & 398,405 & 4.27 \\
5. & Purun plant & $405,782,576$ & 40,578 & 10.78 \\
6. & Household water & $1,023,980,756$ & 102,398 & 170.58 \\
\hline
\end{tabular}

From the Table 1, we can perceive that out of 16.2 billion rupiahs of the Direct Use Value, more than half of them come from rice paddy and the remaining components contribute the rest. 


\subsection{Indirect Use Value}

\subsubsection{Biological Value (BV)}

Calculation of the production value of biological functions can be approximated by calculating the carrying capacity of the marsh ecosystem biota such as fish production per year, proceeds from Galam wood, and Purun plan. It means, the value of biological function is the summation of economic values in beje fishing, fishing gear, Galam wood, and Purun plant and it can be written as:

$$
\begin{aligned}
B V & =\operatorname{Rp}(1,761,779,396+5,108,607,306+842,959,836+405,782,576) \\
& =\operatorname{Rp} 8,119,129,114
\end{aligned}
$$

which is equivalent to $\operatorname{Rp} 811,913$ per hectare.

\subsubsection{Values of Water Storage and Water Recycling (WSWRV)}

In order to determine the physical value of non-tidal swamp as water storage and recycling is done by replacement cost method. This approach is a method of economic valuation. In this research, the economic value of the swamp as storage and water recycling are as follows when we assume that the lowest price is $\mathrm{Rp} 2,450$ as it is mentioned in Suriansah (2012) and average of 4.25 million litters (Notohadinegoro, 1996):

$$
\text { WSWRV }=\left(\frac{4.25 \times 10^{3} \text { liiters }}{1000}\right) \times \operatorname{Rp} 2,450=\operatorname{Rp} 10,412,500 \text { per hectare }
$$

The calculation is based on additional information that one (1) hectare swamps at 1 meter thickness can save as much as 4.0-4.5 million liters.

\subsubsection{Values of Stored Carbon (VSC)}

The value of stored carbon can be sold into international market through the clean development mechanism (CDM). In this research, calculation of the Values Stored Carbon (VSC) is based on estimated available carbon amount by Indonesian Ministry of Forestry, which is approximately 200 tonnes per hectare (Indonesian Ministry of Forestry, 2012). We decided to use the estimated value which was done by the Ministry of Forestry to prevent over estimation. Meanwhile for the same reason, we use lowest value of carbon price, which is USD $5(\operatorname{Rp} 9,500)$ per tonne. Meanwhile, it is known that one hectare peat swamp forests with less than 3 meters deep can reserve up to 200 tonnes of carbon per hectare.

Based on the above information, here are details for the calculation of stored carbon:

$$
\begin{aligned}
V S C & =(200 \times 10,000) \times(\$ 5 \times \operatorname{Rp} 9,500) \\
& =2,000,000 \times \operatorname{Rp} 47,500 \\
& =\operatorname{Rp} 9,500,000 \cong \$ 1000 \text { per hectare. }
\end{aligned}
$$

\subsection{Value of Option for Bio Diversity (VO) and Value of Bequest}

The other two economic values for swamp area in this research are Value of Option for bio diversity (VO) and

\begin{tabular}{|c|c|c|c|c|c|}
\hline \multirow[b]{2}{*}{ No } & \multirow{2}{*}{\multicolumn{2}{|c|}{ Commodities }} & \multicolumn{3}{|c|}{ Area Size } \\
\hline & & & $\begin{array}{l}\text { 10,000 ha } \\
\text { (Rp per year }\end{array}$ & $\begin{array}{c}1 \text { ha } \\
\text { (Rp per year) }\end{array}$ & $\begin{array}{c}1 \text { ha } \\
\text { (USD per year) }\end{array}$ \\
\hline 1. & $\begin{array}{l}\text { Value of Option } \\
\text { Diversity) }\end{array}$ & (Bio & $1,778,640,000$ & 177,864 & 18.72 \\
\hline \multirow[t]{2}{*}{2.} & Value of Bequest & & $1,788,862,000$ & 178,886 & 18.83 \\
\hline & Total & & $3,567,502,000$ & 356,750 & 37.55 \\
\hline
\end{tabular}
Value of Bequest (VB). Based on responses of 150 respondents from 9 villages in the sub district, we found that economic values of both VO and VB components which are available in Table 2. We can see that contribution of Value of Option and Value of Bequest are approximately equal.

Table 2. Value of option and value of bequest of non-tidal swamp ecosystem of sub district Central Tapin and South Candi Laras 
Overall, when we consider all components of the non-tidal swamp ecosystem which are Direct Use Value, Indirect Use Value, Value of Options, and Value of Bequest, then total of economic values of march ecosystem in Sub Distric Central Tapin and South Candi Laras, District Tapin, Province South Kalimantan, which consist of 10,000 hectares area is Rp 227,016,833,000 per year, which is equivalent to USD 2,389.65 per hectare per year.

Out of the total economic value, $7.14 \%$ are economic values, and the other 92.86 are ecological values. That numbers reflect resources and environmental damage of the non-tidal swamp ecosystem even without considering social cost which are generated when there are functional changes from marsh ecosystem to palm oil plantations.

\section{Conclusion}

The research found that the total economic value of non-tidal swamp ecosystem is South Kalimantan area is approximately 227.02 billion rupiahs per year per 10.000 hectares, which is equivalent to USD 2,389.65 per hectare per year. Out of that value, only $7.14 \%$ of them are economic values. Meanwhile, ecological values can obtain about $92.07 \%$ of the total values. This figure also reflects that there will be the value of natural resources and environmental damage from non-tidal swamp ecosystem beside the social costs that would arise, if the assumed conversion plan/swamp land conversion to oil palm plantations covering 10,000 ha implemented. Therefore, the government should be responsible and play an important role in order to protect and preserve the land effort in the interest of a wider audience.

\section{References}

Agus, F., \& Irawan. (2006). Konversi lahan pertanian sebagai suatu ancaman terhadap ketahanan pangan dan kualitas lingkungan.Prosiding seminar multi fungsi dan frevitalisasi pertanian, Bogor, 27-28 Juni 2006. Badan litbang pertanian. Jakarta. Abstrak book. 28 (1). Ministry of Agriculture of Indonesia, Library Center and Agricultural Technology Distribution.

Aimkij, N., Bahaudin, G., \& Tanin, K. (2013). Green Management Sustainability and its Economic Impact. Journal of Economics and Sustainable Development (JESD), 4(6), 104-116.

Dixon, J. A., Scura, L. F., Carpenter, R. A., \& Sherman, P. B. (1994). Economic Analysis of Environmental Impacts. London, Earth Scan Publication.

Manurung, E. G. T. (2011). Analysis of Economic Valuation of Indonesian Palm Oil Plantation. Indonesian Environmental Policy and institutional Strengthen, IQC (EPI).

Mourato, S., Ozdemiroglu, E., \& Foster, V. (2000). Evaluating health and environmental impacts of pesticide use: implications for the design of eco-labels and pesticide taxes. Environmental Science and Technology, 34(8), 1456-1461.

Nautiyal, S., \& Rama, R. N. (2012). Ecological and socioeconomic impacts of conservation policies in biodiversity hotspots: a case study from Rajiv Gandhi National Park, India. Journal of Environmental Studies and Sciences (JESS), 2(2), 165-177. http://dx.doi.org/10.1007/s13412-011-0052-x.

Noor, M. (2007). Rawa Lebak. Ekologi, pemanfaatan dan Pengembanganya. Divisi Perguruan tinggi. PT. Raja Grafindo Persada. Jakarta.

Page, S. E., Siegert, F., Rieley, J. O., Boehm, H. V., Jayak, A., \& Limin, S. (2002). The amount of carbon released from peat and forest fires in Indonesia during 1997. Nature, 420(6911), 61-65.

Pavri, F., Anna, S., Abraham, D., \& Jeand, D. M. (2012). Land use and socioeconomic influences on a vulnerable freshwater resource in Northern New England, United States. Journal of Environmental Development Sustainability (JEDS), 15(3), 625-643.

Roy, M. B., Roy, P. K., Samal, N. R., \& Mazumdar, A. (2012). Socio-economic Valuations of Wetland Based Occupations of Lower Gangetic Basin through Participatory Approach. Environment and Natural Resources Research (JENRR), 2(4), 30-44. http://dx.doi.org/10.5539/enrr.v2n4p30

Sabran., M., Maamun, M. Y., \& Fagi, A. M. (1998). Potensials and Restrictions of the Development of Agricultural Food Plantation in Swamps Area of Kalimantan. Proceeding of Workshop of Development Strategy of Kalimantan Region. Installation for Agricultural Research and Technology of South Kalimantan, Banjarbaru, 2-3 December 1997.

Swamp Crops Research Institute (Balitra). (2011). Potential quagmire in South Kalimantan. Proceeding of Seminar on Oil Palm Plantation Development Wetlands. Banjarmasin, April 10-11, 2011.

Swinton, S. M., Lupi, F., Robertson, G. P., \& Landis, D. A. (2006). Ecosystems Services from Agriculture: 
Looking Beyond the Usual Suspects. American Journal of Agricultural Economics (AJAE), 88(5), 1160-1164. http://dx.doi.org/ 10.1111/j.1467-8276.2006.00927.x

Turpie, J., Lannas, K., Scovronick, N., \& Louw, A. (2010). Wetland Ecosystem Services and Their Evaluation: A Review of Current Understanding and Practice, Wetland Valuation Vol. 1. Water Research Commission Report, No.TT 440/09.

\section{Copyrights}

Copyright for this article is retained by the author(s), with first publication rights granted to the journal.

This is an open-access article distributed under the terms and conditions of the Creative Commons Attribution license (http://creativecommons.org/licenses/by/3.0/). 